\title{
Different presentations of intraretinal fluid collections in optic disc pits: OCT study of 3 cases
}

\author{
Diferentes apresentações das coleções de líquido intra-retiniano nas fossetas \\ do disco óptico: estudo de 3 casos com OCT
}

\author{
Oswaldo Ferreira Moura Brasil ${ }^{1}$ \\ Maria Vitoria Oliveira Moura Brasil ${ }^{2}$ \\ Oswaldo Moura Brasil ${ }^{3}$
}

Trabalho realizado no Instituto Brasileiro de Oftalmologia - IBOL - Rio de Janeiro (RJ) - Brasil.

'Pós-graduando nível Doutorado na Universidade Federal de São Paulo - UNIFESP - São Paulo (SP) - Brasil.

${ }^{2}$ Pós-graduanda nível Doutorado na UNIFESP - São Paulo (SP) - Brasil

Chefe do Setor de Retina e Vítreo e Diretor do IBOL Rio de Janeiro (RJ) - Brasil.

Endereço para correspondência: Instituto Brasileiro de Oftalmologia - Praia de Botafogo, 206 - Rio de Janeiro (RJ) CEP 22250-040

E-mail: dico@unisys.com.br

Recebido para publicação em 21.06.2005

Última versão recebida em 06.12.2005

Aprovação em 11.01.2006

Nota Editorial: Depois de concluída a análise do artigo sob sigilo editorial e com a anuência do Dr. João Carlos de Miranda Gonçalves sobre a divulgação de seu nome como revisor, agradecemos sua participação neste processo.

\section{ABSTRACT}

The congenital optic disc pit is a rare anomaly that can lead to major visual impairment associated with subretinal fluid accumulation. The authors describe the optical coherence tomography study of three cases of untreated congenital optic disc pits with different levels of visual impairment and its different presentations of intraretinal fluid collections.

Keywords: Tomography, optical coherence; Optic disk; Optic disk/abnormalities; Retinal detachment; Retinal detachment/etiology

\section{INTRODUCTION}

Optic disc pits are rare congenital anomalies first described by Wiethe in $1882^{(1)}$, as two black depressions with an olive-gray tint located on the optic nerve head of a 62 year-old woman. Frequency of optic disc pits was estimated to be approximately one in every 11,000 patients $^{(2-3)}$.

Initially, macular changes associated with pits were believed to be coincidental. In 1958, an integral relationship between pits and subretinal fluids was first suggested ${ }^{(4)}$. Nevertheless, the natural history of these fluids has not been well elucidated.

It has been proposed that vitreous could be the origin of the subretinal fluid considering the higher incidence of posterior vitreous detachment in eyes with optic disc pits and retinal detachment ${ }^{(5-6)}$. Others believe that cerebrospinal fluid should be considered as the source of subretinal fluid in eyes with pits ${ }^{(7-8)}$, although no animal or human model has demonstrated a connection between the pit and subarachnoid space. Other possibilities would be leakage from the choroid or from vessels within the pit $^{(9-10)}$.

Optical coherence tomography (OCT) is a modern diagnostic imaging technique that examines living tissue non-invasively with resolution in the order of 10 microns. It is based on a complex analysis of the reflections of low coherence radiation from the tissue under examination and allows images to be obtained for layers of the retina, the choriocapillaris and the retinal pigment epithelium ${ }^{(11)}$.

In this case series, we report the OCT (StratusOCT III: Carl Zeiss Meditec Inc.) study of three cases of untreated congenital optic disc pits with different levels of visual impairment and their distinctive presentations of intraretinal fluid collections.

\section{CASE REPORTS}

\section{Case 1}

A 73-year-old male, with congenital optic disc pit in the right eye and 0.5 
best-corrected visual acuity. In this case we observe a schisis-like cavity coming directly from the pit associated with cystoid macular edema. We can easily distinguish intraretinal accumulation of liquid in well-defined spaces or cavities in the vicinity of external plexiform layer (Figure 1).

\section{Case 2}

A 43-year-old female, with congenital optic disc pit in the left eye and 0.1 best-corrected visual acuity. Besides cystoid edema of the retina at the margin of the optic disc pit, the image discloses serous detachment of the retina at the fovea, where the walls of the retinal cysts disappear and cavities merge (Figure 2).

\section{Case 3}

A 60-year-old female, with congenital optic disc pit in the left eye and vision worse than 0.05 . Serous detachment of the retina appears as the last stage of chronic edema. The sensory retina is elevated by serous detachment through the posterior pole, leading to maximum vision decrease.

\section{DISCUSSION}

In the study of the clinical characteristics of 75 eyes with congenital optic disc pits, it was found that serous retinal detachment or evidence of a previous retinal detachment occurred in $52 \%$ of the eyes ${ }^{(12)}$. In the same study, cystic changes within the detached retina were present in $62 \%$ of these cases.

In 1988, it was proposed that fluid would typically enter the neurosensory retina directly from the pit, separating the inner retinal layers to produce a primary schisis-like macular elevation $^{(13)}$. The author had the opportunity to study and confirm his theory a few years later with assistance of $\mathrm{OCT}^{(14)}$. In that case report, a patient was examined with OCT before and after intravitreal gas tamponade. Before intravitreal gas injection, OCT defined a separation between the inner and outer layers of the retina that connected with the optic disk pit. After pneumatic displacement of the intraretinal and subretinal fluid, OCT disclosed that the two layers were opposed and in contact with the retinal pigment epithelium.

Other OCT studies of macular changes associated with optic disc pits have been described previously.

Some authors found out that 6 out of 8 evaluated patients with congenital optic disc pit had evidence of retinoschisis or cystic changes with or without serous retinal detachment when OCT was performed ${ }^{(15)}$.

Other authors evaluated four eyes of three patients with optic pit-related macular pathology with $\mathrm{OCT}^{(16)}$. They found retinal edema and cystic degeneration overlying macular neurosensory detachment in each eye. They also observed that schisis-like cavity or edematous retina communicated with optic disc in all eyes.

A Brazilian case series described three cases of congenital optic disc pits studied with $\mathrm{OCT}^{(17)}$. Inner retinal layer separation and intraretinal cyst formation were observed. Serous retinal detachment was present in all 3 cases and this may be a sign of chronicity of the disease, even though the stages of the disease were shown separately.

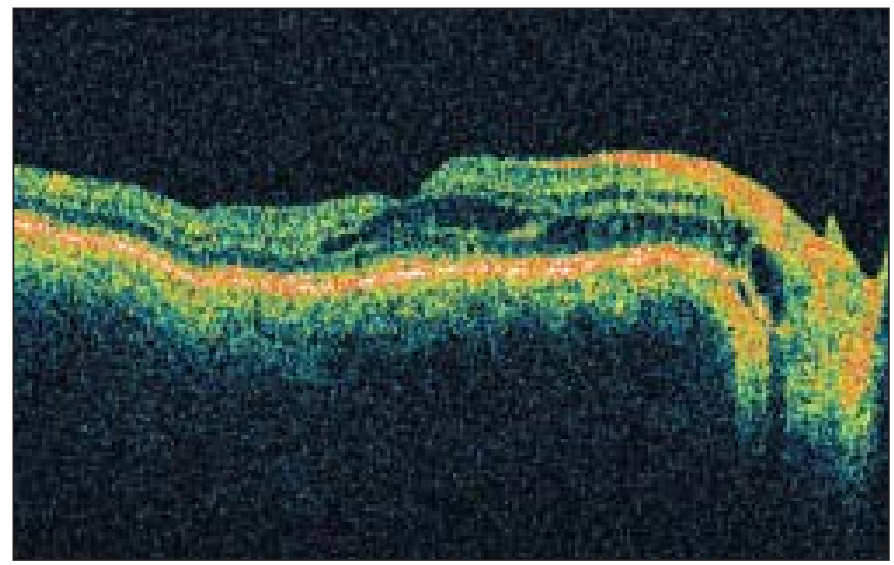

Figure 1 - Schisis-like cavity extending from the optic disc to the macula and cystoid macular edema

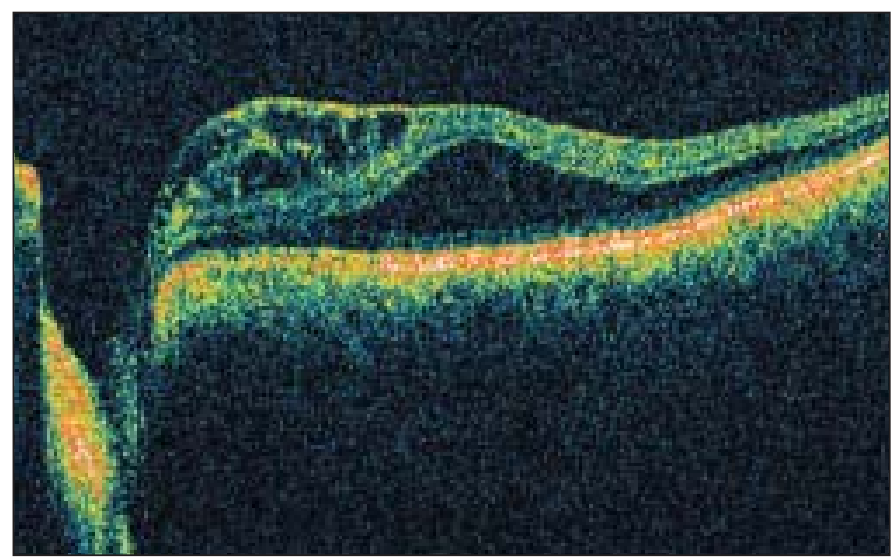

Figure 2 - Intraretinal cysts formation and serous detachment of the retina

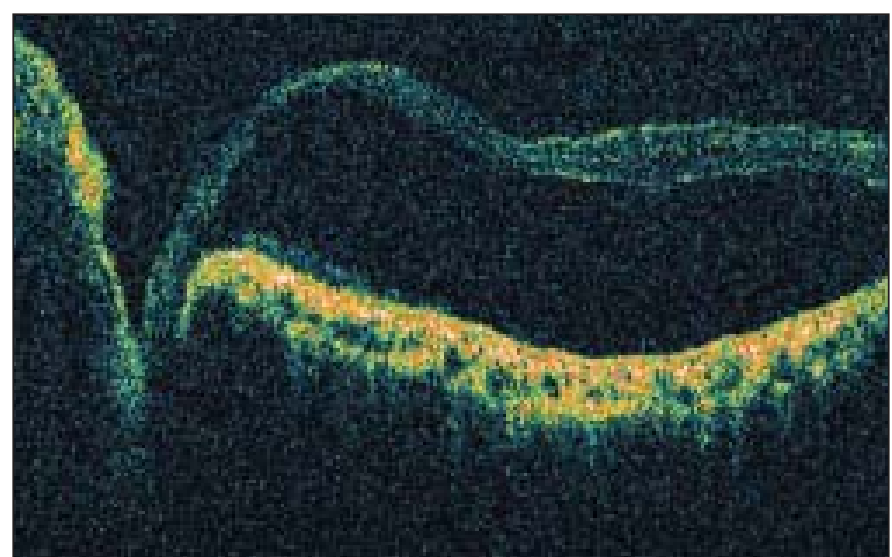

Figure 3 - Serous detachment of the retina 
The present case series has some different aspects that should be highlighted. Some of these aspects were made clearer by the evolution of the OCT equipment with the StratusOCT III used in this study. In Case 1 we can observe the schisis-like cavity described by Lincoff and colleagues extending from the optic disc pit to the macula, where we find cystoid edema. This case may represent the early form of intraretinal fluid accumulation, before serous retinal detachment develops. Case 2 discloses both intraretinal cysts as well as serous macular detachment, in a more severe form of the disease. Case 3 represents the most severe clinical picture of serous retinal detachment in congenital optic disc pits, possibly the last stage of intraretinal fluid collections.

Our series contribution was limited by the study of the cases at only one time period. Follow-up of these changes with OCT could bring further information on the still obscure nature of these fluid collections.

\section{CONCLUSION}

OCT allows detailed anatomical view of the vision-threatening macular changes associated with optic disc pits at all levels of severity.

\section{RESUMO}

A fosseta congênita do disco óptico é uma anomalia rara que pode levar a importante comprometimento visual associado ao acúmulo de líquido sub-retiniano. Os autores descrevem o estudo pela tomografia de coerência óptica de três casos de fossetas congênitas do disco óptico não tratadas com diferente comprometimento visual e diferente apresentação das coleções de líquido intra-retiniano.
Descritores: Tomografia de coerência óptica; Disco óptico; Disco óptico/anormalidades; Descolamento retiniano; Descolamento retiniano/etiologia

\section{REFERENCES}

1. Wiethe T. [Ein Fall von angeborener]. Difformität der Sehnervenpapille. Arch Augenh. 1882;11:14-9. German.

2. Reis W. [Eine wenig bekannte typishe Missbildung am Sehnerveneintritt: unschriebene Grubenbildung auf der Papilla n. optici]. Z Augenheild. 1908;19: 505-28. German.

3. Kranenburg EW. Crater-like holes in optic disc and central serous retinopathy. Arch Ophthalmol. 1960;64:912-24

4. Petersen HP. Pits or crater-like holes in the optic disc. Acta Ophthalmol (Copenh). 1958;36(3):435-43.

5. Sugar HS. Congenital pits in the optic disc with acquired macular pathology. Am J Ophthalmol. 1962;53:307-11.

6. Sugar HS. An explanation for the acquired macular pathology associated with congenital pits of the optic disc. Am J Ophthalmol. 1964;57:833-5.

7. Regenbogen L, Stein R, Lazar M. Macular and juxtapapillar serous retinal detachment associated with pit of optic disc. Ophthalmologica. 1964;148:247-51.

8. Gass JD. Serous detachment of the macula. Secondary to congenital pit of the optic nervehead. Am J Ophthalmol. 1969;67(6):821-41.

9. Wise GN, Dollery CT, Henkind P. The retinal circulation. New York: Harper \& Row; 1971.

10. Gordon R, Chatfield RK. Pits in the optic disc associated with macular degeneration. Br J Ophthalmol. 1969;53(7):481-9.

11. Brancato R, Lumbroso B. Guide to optical coherence tomography interpretation. Roma: Innovation-News-Communication; 2004.

12. Brown GC, Shields JA, Goldberg RE. Congenital pits of the optic nerve head II. Clinical studies in humans. Ophthalmology. 1980;87(1):51-65.

13. Lincoff H, Lopez R, Kreissig I, Yannuzzi L, Cox M, Burton T. Retinoschisis associated with optic nerve pits. Arch Ophthalmol. 1988;106(1):61-7.

14. Lincoff H, Schiff W, Krivoy D, Ritch R. Optic coherence tomography of optic disk pit maculopathy. Am J Ophthalmol. 1996;122(2):264-6.

15. Krivoy D, Gentile R, Liebmann JM, Stegman Z, Rosen R, Walsh JB, Ritch $\mathrm{R}$. Imaging congenital optic disc pits and associated maculopathy using optical coherence tomography. Arch Ophthalmol. 1996;114(2):165-70.

16. Rutledge BK, Puliafito CA, Duker JS, Hee MR, Cox MS. Optical coherence tomography of macular lesions associated with optic nerve head pits. Ophthalmology. 1996;103(7):1047-53.

17. Rosa AAM, Nakashima Y, Souza EC. Aspectos à tomografia de coerência óptica de fosseta congênita do nervo óptico: relato de 3 casos. Arq Bras Oftalmol. 2002;65(3):369-73. 